Christina Osbeck*, Olof Franck, Annika Lilja, Karin Sporre, Johan Tykesson

\title{
Abilities, knowledge requirements and national tests in RE - The Swedish case as an example in the outcome-focused school and society of today
}

https://doi.org/10.1515/zpt-2018-0056

\begin{abstract}
The aim of this article is to present the system that governs Swedish $\mathrm{RE}$ in terms of curricular requirements, national tests and their outcomes, and discuss this in light of the current critical debate on an outcome-focused school, as well as the debate on the need for 'powerful knowledge'. The debate on educational achievements and measurements can be seen from different angles. On the one hand, there are reasons to take the criticisms seriously, for instance concerning how such a focus tends to instrumentalise and superficialise knowledge and education. On the other hand, from a societal perspective, one has to ensure that all students, through their education, have opportunities to develop powerful knowledge that helps to explain the world so that school can contribute to social justice. Against such a background, the Swedish system is described as a rather strongly steering system that regulates schools through curricula but also monitors them through national tests. Through a brief presentation of empirical findings from the EthiCo project, it is shown how this system in practice limits the students' chances of acquiring a multidimensional ethical competence and instead highlights a one-dimensional argumentative competence. Such a teaching runs the risk of reducing rather than widening students' ethical competence.
\end{abstract}

Zusammenfassung: Ziel dieses Beitrags ist es, das System vorzustellen, das den schwedischen Religionsunterricht im Blick auf curriculare Vorgaben, nationale Tests und ihre Ergebnisse steuert, und dies im Lichte der gegenwärtigen kritischen Debatte über eine outcome-fokussierte Schule sowie der Debatte über den Bedarf an „machtvollem Wissen“ zu erörtern. Die Debatte über pädagogische Leistungen und Messungen kann aus verschiedenen Blickwinkeln betrach-

*Kontakt: Docent Dr. Christina Osbeck, Department of Pedagogical, Curricular and Professional Studies, Box 300, 40530 Göteborg, Schweden, E-Mail: christina.osbeck@gu.se 
tet werden. Einerseits gibt es Gründe, die Kritk ernst zu nehmen, zum Beispiel im Blick darauf, wie eine solche Schwerpunktsetzung dazu führt, Wissen und Bildung $\mathrm{zu}$ instrumentalisieren und oberflächlich werden $\mathrm{zu}$ lassen. Anderseits muss aus einer gesellschaftlichen Perspektive dafür gesorgt sein, dass alle Schülerinnen und Schüler durch ihre Bildung die Möglichkeit haben, machtvolles Wissen auszubilden, das dazu verhilft, die Welt erklären zu können, so dass die Schule zu sozialer Gerechtigkeit beitragen kann. Vor diesem Hintergrund wir das schwedische System als stark steuernd beschrieben, da es Schulen durch Curricula reguliert und sie zudem durch nationale Tests überwacht. Mit einer knappen Vorstellung empirischer Befunde aus dem Ethico-Projekt wird gezeigt, wie dieses System in der Praxis die Möglichkeiten der Schülerinnen und Schüler im Blick auf den Erwerb einer multidimensionalen ethischen Kompetenz einschränkt und stattdessen eine eindimensionale argumentative Kompetenz privilegiert. Eine solche Art des Unterrichtens läuft Gefahr, der ethischen Kompetenz der Schülerinnen und Schüler Abbruch zu tun statt sie zu erweitern.

Keywords: Ethics; Moral education; Competence; Curriculum, Test

Schlagworte: Ethik; moralische Erziehung; Kompetenz; Curriculum; Test

\section{Introduction}

In recent years, public educational discourse worldwide has been rather focused on achievements, measurements and international comparisons (Smith, 2016). In relation to this, a debate within educational research about what such a trend means, in general and particularly in the field of religious and ethics education, is important.

One aspect of this public debate on achievements has been the effort to govern and direct education. Both in EU policy and in national curricula, the tendency to describe educational expectations in terms of competences has become common. In Sweden, the concept competence [kompetens] is not present in the current national curriculum, which was enacted in 2011. Instead, 'knowledge requirements' [kunskapskrav] are central here. These requirements are rather detailed and in this respect, they differ quite a lot from the "goals" and "goals to strive for", the expressions used in the previous curriculum (Lpo 94). Along with the latest curriculum reform, the government introduced national tests in many more subjects and for more age groups than previously. Religious education (RE) was one of the subjects in which roughly 25000 pupils per year in grade six and 25000 students per year in grade nine were to be evaluated as having or 
not having an approved level of knowledge. Such a situation highlights the question of which knowledge is emphasised in a field. In 2014, the Swedish Research Council granted funding to a project on varieties of conceptions of ethical competence (EthiCo) which stresses that what is seen to constitute knowledge within ethics education is somewhat disputed and is potentially limited in the Swedish curriculum. This text draws on findings from the project. ${ }^{1}$

The aim of the article is to present the system that governs Swedish RE in terms of curricular requirements, national tests and their outcomes, and discuss this in light of the current critical debate on an outcome-focused school as well as the debate on the need for 'powerful knowledge'.

\section{Desirable school knowledge as competences}

\section{Trends, criticisms and overlooked opportunities}

The trend of expressing curricular expectations in the form of 'competences' is here interpreted as one variety of a broader focus on outcomes in European curricula (Lind, 2012). Even if this "language of competences", the focus on learning outcomes, the test culture and the achievement era are closely linked to each other, there are reasons not to regard them, entirely, as expressions of the same thing.

The measuring trend can be considered from different angles. Even if it is hardly controversial that authorities and politicians have a desire to carefully follow up on how education develops, repeated assessments carry the risk of resulting in an instrumental view of knowledge. This does not highlight the development of knowledgeable and wise individuals (see e.g. Tröhler, 2011 on Bildung), who together form a community, but the scores and achievements as such (Biesta, 2012; 2011).

An approach that is focused on learning outcomes tends to make invisible that one important quality of education is its "unexpectedness" (Olson, 2017). This is a part of the "beautiful risk" of education that characterises the enterprise (Biesta, 2013). Instead of structured lessons strictly related to certain learning outcomes, education must reserve space for the unexpected. It must allow room for "teachers, students and subject content to come into being in the meeting

1 The EthiCo project 'What may be learnt in ethics? Varieties of conceptions of ethical competence to be taught in compulsory school' (Dnr 2014-2030) is funded by the Swedish Research Council. The project members are the authors of this article and Christina Osbeck is the PI. 
with each other in ways that do not only position them as objects to be kneaded and shaped based on substantially given end destinations with regard to different types of learning and knowledge objectives" [our translation] (Olsson, 2017, ii).

However, there are students who cannot afford for education to be risky and learning to be something unexpected. An outcome-focused school can be argued for from a social justice perspective, at least if these learning outcomes can be described as powerful knowledge, i. e. knowledge that helps one to understand and explain the world in better ways (Young, 2013). If one considers powerful knowledge to be something that all students should have the right to be offered, it is reasonable that one would have an interest in following up educational processes. In a way that is reminiscent of Basil Bernstein's distinction between horizontal and vertical discourse (1999), Michael Young regards disciplinary, specific and hierarchical language as providing the possibility of transgressing the limitations of everyday practices and contextual knowledge. School should make social mobility possible (e.g. Frykman, 1998), and an interest in assessment and learning outcomes could be seen as one step on the road to securing this possibility.

One criticism of the broad and overarching way of formulating learning outcomes as competences has been that it can be regarded as part of a language of learning that marginalises content and purpose in education. The criticism stresses that learning is not an end in itself. It is always about something for particular purposes and made possible in relation to certain contexts and people (Biesta, 2012). An educational language must address content, purpose and relationships (ibid).

However, the language of competences can be used in different ways: it may reveal an interest in contextually bound skills but also in transferable individual capacities developed over the course of years (Eraut, 1998). Moreover, in the field of ethics, for instance, the language of competences also seems to allow the possibility of expressing what knowledge an ethically competent person should have (Cooper \& Menzel, 2013). That the language of competences shows knowledge as contextualised (De Schrijver \& Maesschalck, 2013; Bernstein, 1999), may depending on perspective - be seen as a special strength of this language.

Even if the interest in assessment can be understood as a sign of a desire for high-quality education, there may be reasons to be sceptical regarding whether a competence-based curriculum can capture all the ingredients that are central for a high-quality education. In addition to goals and content, good teaching is also about processes and about taking into account the abilities of the people involved, i.e. students as well as teachers (Schweitzer, 2006). 


\section{Empirical research on the outcome-focused society in the form of school testing}

In Sweden, there has been a great deal of interest lately in the operationalisations of the learning outcomes of curricula into national tests, in RE as well as other subjects. Therefore, empirical studies concerning effects of such testing are of importance. Children's (9-10 years) experience of a change in classroom climate when national tests take place is one example of this (Silfver, Sjöberg, \& Bagger, 2013; 2016). Individual work replaces the usual cooperative pedagogical practices such as joint discussions. The teacher changes from someone who assists work to someone who controls the students. In reaction to the national tests, students (11-13 years) have expressed that they feel alone in preparing for the tests and not sufficiently assisted by their teachers (Löfgren \& Löfgren, 2015). Furthermore, students identify themselves as "good" or "bad" test-takers and differentiate between high- and low-stake tests (Löfgren \& Löfgren 2016; 2017). The tendency for school to foster competitiveness, transforming cooperative strategies into cheating, is well-known as the hidden curriculum which is sometimes seen as the real purpose of education (e.g. Jackson, 1968; Bourdieu \& Passeron, 1980). However, these tendencies seem to be accentuated in this new test-centred and performance-focused era.

It is known from international studies that a test-centred education also means less time for teaching, an adjustment of curriculum content in order to mirror the tests and a reduction in time spent on curriculum areas other than those assessed (e.g. Polesel, Rice \& Dulfer, 2014). This means that the tests can contribute to constraining students' educational experiences, which is even more serious when one considers how the tests prioritise measurable knowledge and leave out critical and reflective abilities due to difficulties in assessing them (cf. Alexander, 2016). The effects of the tests on teaching and learning may also relate to the fact that tests tend to have an impact on the textbooks on the market that mediates the perspectives of the tests (Conroy, 2013). 


\section{The Swedish model}

\section{Lgr 11 - Aim, core content, knowledge requirements}

The general, introductory part of the Swedish curriculum (Skolverket, 2011) states fundamental values and overall goals, as well as responsibilities for staff working in the nine grades of compulsory school, ${ }^{2}$ followed by syllabuses for each school subject [kursplaner]. The structure of the syllabus is the same for all subjects: aim, core content and knowledge requirements, where the aim-section applies to all nine years in compulsory school, while the core content and knowledge requirements are specified in three parts: for years 1 to 3,4 to 6 , and 7 to 9 respectively. The knowledge requirements are additionally specified in three different categories indicating what is required for different marks. The knowledge requirements are the most extensive section of the three. Generally, the syllabuses are written in a concise style, for example using bullet points in the descriptions of core content and presenting the knowledge requirements in a table.

Various abilities are described in the aim-section of the syllabuses. In RE, five abilities are given of which four are related to the four sub-areas of the RE subject presented in the core content, i. e. Religions and other outlooks on life, Religion and society, Identity and life issues, and Ethics. The fifth ability is a general ability related to information retrieval and source criticism when studying religions. As an example of these abilities, the one related to the subarea Ethics can be given: "Teaching in religion should essentially give pupils the opportunities to develop their ability to [...] reason and discuss moral issues and values based on ethical concepts and models" (Skolverket, 2011, 176).

The abilities are related to the knowledge requirements, which for instance is made explicit in the national tests where these requirements are tested. These abilities are perhaps the closest one gets to what might be called a competence in the Swedish curriculum, but ability [förmåga] is the term used. However, the most influential section of the curriculum is the knowledge requirements that the students are graded on, which are also usually more specific and content-related than the abilities. ${ }^{3}$

2 A full English version of the Swedish curriculum including the RE syllabus can be found at: https://www.skolverket.se/publikationer?id=2687

3 With regard to Ethics, both the related ability given in the aim-section and the knowledge requirements are rather abstract, and the difference between them in this respect is subtle. 


\section{The national tests}

The 2013 national tests in RE, which are the only ones openly available for research, consisted of 24 questions for grade 9 and 21 for grade 6. In 2016, tests in several subjects were discontinued for grade 6, including the one in RE. Since 2011, the national tests in RE are developed by staff at the University of Gothenburg, commissioned and directed by the Swedish National Agency for Education. The test is supposed to guide the teachers in the grading of their students. As examples of the knowledge requirements to be tested in grade 6 and 9, the ones for Ethics will be mentioned. In the examples here, the requirements for the highest grade are presented and the expressions that are characteristic of the highest grade are shown in bold print: "Pupils can apply well developed reasoning to daily moral questions and what it might mean to do good. Pupils make reflections which carry the reasoning forward and deepen or broaden it and use some ethical concepts in a well functioning way." (for grade 6; Skolverket, 182). "Pupils can reason and argue about moral issues and values by applying well developed and well informed reasoning, and use ethical concepts and models in a well functional way." (For grade 9; Skolverket, 184).

The knowledge requirements of the Swedish RE syllabus concerning Ethics can be interpreted as primarily emphasising an argumentative competence, so of course, it is possible to think of other central ethical competences that are not included. The absence of more complex knowledge forms may be due to the brief style and the fact that it should be possible to transform the knowledge requirements into measurements (cf. Sporre, 2018a).

\section{EthiCo - beyond knowledge requirements and national tests}

The EthiCo project was developed from the starting point that there are reasons to believe that the knowledge requirements and national tests limit central knowledge in a field. The EthiCo project focuses on the sub-area Ethics within the subject of RE in Sweden and has the purpose of identifying and elucidating varieties of conceptions of ethical competence as well as critically analysing and discussing them in relation to each other and in relation to ethical theory as potential content in ethics education in compulsory school. The interest is in varieties of conceptions of ethical competence beyond the analytical and argumentative competences emphasised in the knowledge requirements and national tests. In the EthiCo project, ethical competence was used heuristically as a broad and 
open concept with the intention of bridging different forms of knowledge, skills and abilities, as well as different labels for such resources (Osbeck et al., 2018; Osbeck, 2018). The purpose of the project is fulfilled through empirical analyses of 1 ) the tests as a. operationalisations of the requirements, b. findings and information about the ethical competences required of students, and c. findings and information about additional ethical competences shown by students, 2) international curricula, 3) Swedish teachers' view on central ethical competences and 4) students' view on central ethical competences. In the presentation below, some of the main findings are summarised and references are given to full presentations of the different studies.

As expected, and as can be seen below, findings from the project show additional ethical competences to those tested in the national tests. Analyses of the test constructions show how the knowledge requirements have directed the tests, as well the assessment instructions for the tests. The focus on testing reasoning in ethics is shown to be unfavourable to ethics education, as other dimensions of ethics education are neglected (Sporre, 2018a).

The findings from a systematically drawn sample from the 47266 grade 6 and 9 tests - i.e. 3102 student tests - show that students' grades were in general lower on the tasks related to the sub-area of Ethics than the tasks referring to the two sub-areas related to religions (Tykesson, 2017). However, this does not mean that it is possible to claim that the ethics part of the subject is generally the more difficult one since there was a larger proportion of multiple choice items for the sub-areas related to religions than for the sub-area of Ethics. In addition, whether a task is solved to a higher or lower degree than average varies between the ethics tasks. Another circumstance that makes it hard to draw conclusions about groups of tasks (Ethics-Religions) in a test aiming at high inner consistency, is that results on different tasks correlate highly with each other. However, it is clear that girls generally perform better than boys on the RE national test and that native speaking students perform better than non-native speaking students (Tykesson, 2017). ${ }^{4}$

A subsequent reanalysis and close reading of a systematic sample of students' answers to the ethics tasks - in sum 200 test texts - has indicated that wider ethical competences are shown than the ones that students are supposed to receive credit for according to the assessment instructions (Osbeck, 2017; Sporre, 2018b). In particular, abilities to weigh values in relation to each other and argue for collective and societal values, in line with the introductory part of the Swedish curriculum, are shown - although not given credit.

4 The Swedish national RE test of 2013 can be downloaded in its entirety at: https://idpp.gu.se/ forskning/utvecklingsprojekt/nationella-prov/religionskunskap 
The limitations of the ethical competences assessed in the Swedish national tests can also be seen from comparisons and analyses of international curricula. Text analyses of Nordic curricula show, for instance, an absence of action competence in the Swedish one (Lilja et al., 2018). Analysis of the curricula from Namibia, South Africa, California State and the Province of Québec indicate an individualistic nature of the Swedish curriculum, which to a large extent fails to place ethical competences in a societal context by addressing current issues such as multi-cultural and citizen-oriented topics (Sporre, 2017).

In the group interviews, teachers from eight different schools and municipalities (14 groups) stress as important ethical competences, beyond those in the Swedish knowledge requirements, an understanding of ethical dilemmas, often everyday life events. Such an understanding may be of an empathic kind but may also be a reflexive understanding, drawing on, for instance, critical thinking. How ethical competence may be related to a perseverance competence is also shown through the interviews as well as the centrality of action competence.

From the perspective of the interviewed students - in total 16 groups from the same schools as the interviewed teachers - ethical competence is a rather contextual, holistic, procedural and everyday-life-related competence. This perspective clearly includes a weighing of values in relation to each other. The needs expressed by the students regarding ethical competence are related to certain situations of which some are mentioned more frequently than others. Values, situations and needs for ethical competences are intertwined in the interviews with the students. Here an identifying competence concerning ethical issues is stressed as well as a carrying out competence and a reconsidering competence, i.e. taking responsibility for previous decisions.

Previous research stresses, in addition to the argumentative ethical competences in the Swedish curriculum, the importance of an identifying competence, a competence to be informed and knowledgeable about ethical issues, but also an action competence, as well as a perseverance competence (Osbeck et al., 2018).

\section{Concluding remarks}

This article has stressed how the language of competences is a part of an outcome-focused language frequently used in curricula nowadays. Even if a focus on learning outcomes can be criticised for having an instrumentalising view of knowledge, this article has also pointed to the importance of school in contributing to powerful knowledge, in relation to which an interest in learning outcome might be understandable. Although the language of competences in the curric- 
ulum may be limiting in some respects, in the Swedish context it is more the national testing that has contributed to such limitations. There are central aspects of an ethical competence that have been identified in research, for example in the EthiCo project, that are not taken into account in the knowledge requirements and therefore not tested. This means that there are serious reasons to believe that the testing and its teaching-to-the-test effects may restrict students' development of ethical competences in Sweden.

While this article was being written, the Swedish Minister of Education and the National Agency for Education announced a rewriting of the knowledge requirements of the curriculum. To what extent this will also have consequences for the national tests is a question that remains to be answered. Since the Agency has invited curriculum researchers in general to engage in this work, one might expect that research such as that developed in the EthiCo project will be taken more into account and that the new curriculum will therefore be more varied.

One possible contribution of the EthiCo project, even while still in progress, to such a discussion about changes in the curriculum would be to point out the need to change the one-dimensional understanding of ethical competence - the argumentative competence - into a multi-dimensional understanding of ethical competence. What has been briefly presented in this article is how the empirical analyses of the different materials in the EthiCo project have identified an understanding of ethical competence that goes beyond the curricular requirements and national tests. A summary of such identified competences, beyond the argumentative competence stressed in the Swedish syllabus, are: an identifying competence concerning e.g. ethical dilemmas in everyday life; a weighing competence in relation to collective and societal values; a competence of being well-informed about the issues at stake, an action competence, a perseverance competence, a reconsidering competence, but also a competence to contextualise ethical issues in the multi-cultural and global society of today. A frequently cited scholar who conceptualises morality broadly, in four components, is James Rest (e.g. 1986). Without discussing the psychological foundations of his theory, the four components - moral sensitivity, moral judgement, moral motivation and moral implementation - seem fundamental in their way of capturing most of the dimensions that the EthiCo project has empirically identified, and also many of the perspectives on ethical competence that can be identified in empirical research (Osbeck et al 2018). Rest's concepts, in addition to the EthiCo empirical findings, seem helpful in order to conceptualise and visualise a multi-dimensional understanding of ethical competence that could possibly replace the dominant one-dimensional understanding of ethical competence of the Swedish syllabus and national tests.

In order to develop educational quality, factors other than goals and curriculum content need to be focused on, however, as stressed previously. How 
teaching processes and classroom communication develop is one such factor, as well as the abilities of teachers and students (Schweitzer, 2006). One of the most important issues hindering school quality from improving in Sweden today is the segregation of schools. The possibility of choosing schools freely and the different requirements of these schools regarding student achievements is one part of the segregation. The increasing segregation in living areas of Swedish society is another. A high-quality school system must be able to realise social mobility. That means that a high-quality RE needs to provide students with powerful knowledge concerning both a better understanding of religion and society, and an ethicalexistential competence that also includes the very courage to be - however difficult it may be to measure such a competence.

\section{References}

Bernstein, B., Vertical and Horizontal Discourse: An essay. In: British Journal of Sociology of Education 20(1999), 157-173.

Biesta, G., The Beautiful risk of Education. New York (Taylor \& Francis) 2013.

Biesta, G. (2012). The future of teacher education: Evidence, competence or wisdom? In: Research on Steiner Education, 3(1), 8-21.

Biesta, G. J. J., Good Education in an Age of Measurement: Ethics, Politics, Democracy (Interventions: Education, Philosophy, and Culture), Abingdon Oxon/New York (Routledge) 2011.

Bourdieu, P., \& Passeron, J.-C., Utbildningssystemets ideologiska funktion. In: J. B. Berner, S. Callewaert \& H. Siberbrandt (ed.), Skola, ideologi och samhälle. Ett kommenterat urval franska utbildningssociologiska texter av Bourdieu/Passeron, Baudelot/Establet, Poulantzas. Stockholm (Wahlström \& Widestrand) 1980, 56-76.

Conroy, J.C., Does religious education work? A multi-dimensional investigation. London (Bloomsbury Academic) 2013.

Cooper, T. L., \& Menzel, D. Z., In Pursuit of Ethical Competence. In: Cooper, T. L. \& Menzel, D. Z. (ed.): Achieving Ethical Competence for Public Service Leadership, Armonk, New York and London, England (M. E. Sharpe) 2013, 3-23.

De Schrijver, A., \& Maesschalck, J., A New Definition and Conceptualization of Ethical Competence. In: Cooper, T. L. \& Menzel, D. Z. (ed.): Achieving Ethical Competence for Public Service Leadership, Armonk, New York and London, England (M. E. Sharpe) 2013, 29-50.

Frykman, J., Ljusnande framtid!: skola, social mobilitet och kulturell identitet. Lund (Historiska media) 1998.

Jackson, P.W., Life in classrooms. New York (Holt, Rinehart \& Winston) 1968.

Young, M. (2013). Overcoming the crisis in curriculum theory: A knowledge-based approach. Journal of curriculum studies, 45(2), 101-118.

Lilja, A., Franck, O., Osbeck, C., \& Sporre, K., Ethical competence-a comparison between the Swedish and the Icelandic curricula and some teachers' views. In: Education 3-13, 46(2018), 506-516.

Lind, G., Moral Competence and Democratic Ways of Life. In: W. Weber, M. Thoma, A. Ostendorf, \& L. Chisholm, L. (Eds.), Democratic competences and social practices in organizations. Wiesbaden (VS Verlag für Sozialwissenschaften) 2012. 
Löfgren, H., \& Löfgren, R., Alone with the test: Students' perspectives on an enacted policy of national testing in Swedish schools. In: Utbildning och lärande, 9(2015), 35-49.

Löfgren, R., \& Löfgren, H., Att få sina första betyg: En rapport om elevers berättelser om sina erfarenheter av att få betyg i årskurs 6. Stockholm (Skolverket) 2016.

Löfgren, R., \& Löfgren, H., Swedish students' experiences of national testing in science: A narrative approach. In: Curriculum Inquiry 47(2017), 390-410.

Olson, M., Det oväntade i SO-ämnenas undervisning - bjudningar till annat kunskapande och tillblivande. Editorial. In: Nordidactica - Journal of Humanities and Social Science Education 2/2017, i - vii.

Osbeck, C., Ethical competences in pupils' texts: Existential understandings and ethical insights as central but tacit in the curriculum. In: 0. Franck (ed.), Assessment in Ethics Education. A case of national tests in religious education. Dordrecht (Springer International Publishing) 2017, 87-113.

Osbeck, C., Franck, O., Lilja, A., \& Sporre, K., Possible competences to be aimed at in ethics education-Ethical competences highlighted in educational research journals. In: Journal of Beliefs \& Values 39(2018), 195-208.

Osbeck, C. Values and existential understandings as parts of pupils' ethical competence. In: J. Astley, L.J. Francis, \& D.W. Lankshear (Eds.). Values, Human Rights and Religious Education: Contested Grounds. Bern (Peter Lang) 2018, 19-37.

Polesel, J., Rice, S., \& Dulfer, N., The impact of high-stakes testing on curriculum and pedagogy: a teacher perspective from Australia. In: Journal of Education Policy, 29(2014), 640-657.

Rest, J. R., Moral Development: Advances in Research and Theory. New York (Praeger) 1986.

Schweitzer, F., 'Guter Religionsunterricht' - aus der Sicht der Fachdidaktik. In: Was ist guter Religionsunterricht? In: C. Bizer, R. Degen, R. Englert, H. Kohler-Spiegel, N. Mette, F. Rickers \& F. Schweitzer (eds.). Jahrbuch der Religionspädagogik, Neukirchen-Vluyn (Neukirchener Verlag) 2006.

Silfver, E., Sjöberg, G., \& Bagger A., Changing our methods and disrupting the power dynamics: National tests in third-grade classrooms. In: International Journal of Qualitative Methods 11(2013), 39-51.

Silfver, E., Sjöberg, G., \& Bagger, A., An ‘appropriate’ test taker: the everyday classroom during the national testing period in school year three in Sweden. In: Ethnography and Education 11(2016), 237-252.

Skolverket, Curriculum for the compulsory school system, the pre-school class and the leisure-time centre. Stockholm (Skolverket) 2011.

Smith, W. C. (Ed.), The global testing culture: Shaping education policy, perceptions, and practice. Oxford (Symposium Books) 2016.

Sporre, K., 'Vad kan man lära sig i etik?' Conference presentation to Nationell konferens i pedagogiskt arbete, 14-15 ${ }^{\text {th }}$ August, 2017, Gothenburg University.

Sporre, K. (2018a). Assessing ethics education through national tests - an advantage, or not? Journal of Curriculum Studies.

Sporre, K. (2018b). Ethical concepts according to 12-year-olds - students' responses, national tests, and ethics education. In: Ristiniemi, J., Skeie, G. \& Sporre, K. (eds.) Challenging life. Existential questions as resources in education. Münster: Waxmann, 279-296.

Tröhler, D., Languages of education: Protestant legacies, national identities, and global aspirations. New York, NY (Routledge) 2011.

Tykesson, J., Differential Item Functioning in the National Tests in Religious Education in Sweden. In: O. Franck (ed.), Assessment in Ethics Education. Cham: Springer. 2017, 145-162. 